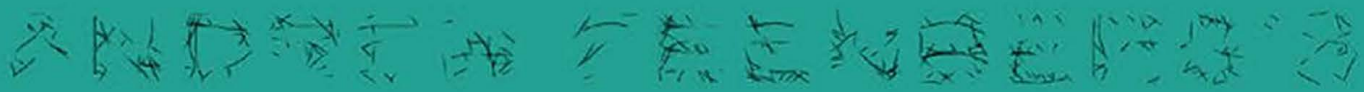

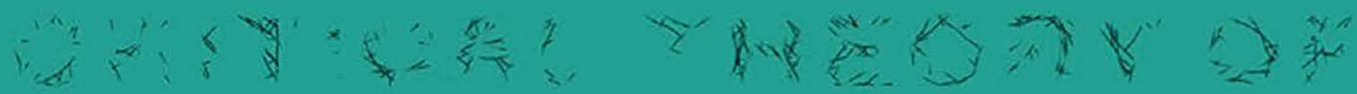

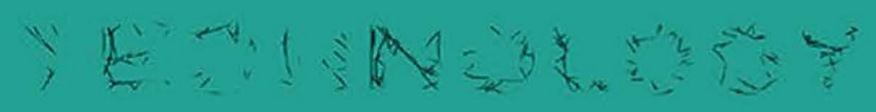

wite

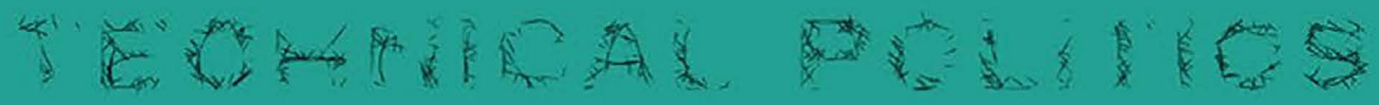

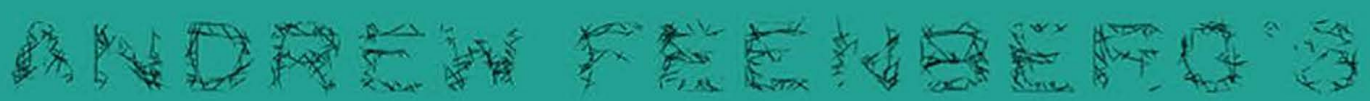

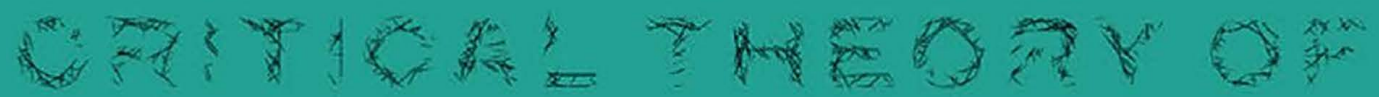
CEN

\title{
GRAEME KIRKPATRIOK
}

\section{TEOHNICAL POLITICS}

ANDREW FEENBERG'S CRITICAL THEORY OF TECHNOLOGY Downloaded from manchesterhive.com at $04 / 26 / 2023$ 07:45:21AM 


\section{Technical politics}

\section{MANCHESTER 1824}

Manchester University Press 
Graeme Kirkpatrick - 9781526105349 Downloaded from manchesterhive.com at $04 / 26 / 2023$ 07:45:21AM via free access 


\section{Technical politics}

\section{Andrew Feenberg's critical theory of technology}

Graeme Kirkpatrick

Manchester University Press 


\section{Copyright $\odot$ Graeme Kirkpatrick 2020}

The right of Graeme Kirkpatrick to be identified as the author of this work has been asserted by him in accordance with the Copyright, Designs and Patents Act 1988.

This electronic version has been made freely available under a Creative Commons (CC-BY-NC-ND) licence, which permits non-commercial use, distribution and reproduction provided the author(s) and Manchester University Press are fully cited and no modifications or adaptations are made. Details of the licence can be viewed at https://creativecommons.org/licenses/by-nc-nd/4.0/

Published by Manchester University Press

Altrincham Street, Manchester M1 7JA

www.manchesteruniversitypress.co.uk

British Library Cataloguing-in-Publication Data

A catalogue record for this book is available from the British Library

ISBN 9781526105325 hardback

ISBN 9781526105349 open access

First published 2020

The publisher has no responsibility for the persistence or accuracy of URLs for any external or third-party internet websites referred to in this book, and does not guarantee that any content on such websites is, or will remain, accurate or appropriate.

Typeset by Newgen Publishing UK 